\title{
Analisis Semiotika Peirce pada Sampul Majalah Tempo Edisi Jokowi Beserta Bayangan Pinokio
}

\author{
Theodora Edra Pramaskara \\ Fakultas Ilmu Sosial dan Ilmu Politik, Universitas Indonesia \\ theodora.edra01@ui.ac.id
}

\begin{abstract}
Tempo Magazine reaped pros and cons when publishing the magazine cover on September 16, 2019. The reason is the illustration shown is a male figure resembling Joko Widodo (Jokowi), but with a long-nosed shadow that is identical to the character of Pinocchio. Many Jokowi Mania Volunteer groups (Jokman) filed a report to the press council because the illustration was considered insulting to the president. However, others support Tempo Magazine's action and are strengthened by the momentum of the publication that coincided with Jokowi's action, which passed the revision of the Corruption Eradication Commission (KPK) Law. It is entrancing to find out the reality of Tempo Magazine construct through semiotic analysis to trigger public debate. By relying on the constructivism paradigm, literature review data collection, and qualitative approach, this descriptive study aims to analyze the discourse in the text on the cover of Tempo Magazine. Through a literature review procedure and qualitative approach, this study explored the discourse in the text on the Tempo Magazine's cover using the constructivism paradigm. Charles Sanders Peirce's Semiotic Theory and Metaphor Theory were used as the point of the analysis in this study. It shows that the caricature on Tempo Magazine's cover is a form of public criticism of the era of Jokowi's leadership as the president. Based on the study results, Jokowi's frowning face and the shadow of Pinocchio's nose are implicitly metaphors for a leader who has broken promises to his people in the context of strengthening the anti-corruption agency of the KPK.
\end{abstract}

Keywords: Joko Widodo; metaphor; semiotics; Peirce; Tempo's cover magazine

\begin{abstract}
Abstrak
Redaksi Majalah Tempo menuai pro dan kontra ketika menerbitkan sampul majalah pada tanggal 16 September 2019. Pasalnya ilustrasi yang ditampilkan merupakan sosok pria menyerupai Presiden Joko Widodo (Jokowi), namun disandingkan dengan bayangan berhidung panjang yang identik dengan tokoh Pinokio. Menanggapi hal tersebut, sebagian masyarakat yang tergabung dalam kelompok Relawan Jokowi Mania (Jokman) melayangkan laporan kepada Dewan Pers karena ilustrasi tersebut dinilai menghina presiden. Meski demikian, tidak sedikit masyarakat yang mendukung tindakan Majalah Tempo. Pemberian dukungan terhadap Redaktur Tempo juga diperkuat dengan momentum penerbitan majalah yang bertepatan dengan tindakan Jokowi yang justru meloloskan revisi Undang-Undang Komisi Pemberantasan Korupsi (UU KPK). Melalui analisis semiotika, menarik untuk mengetahui realitas yang ingin dikonstruksikan Redaktur Tempo hingga memicu perdebatan masyarakat. Dengan bersandar pada paradigma konstruktivisme, pengumpulan data tinjauan literatur, serta metode atau pendekatan kualitiatif, penelitian deskriptif ini bertujuan untuk menganalisis retak teks pada sampul Majalah Tempo. Teori Semiotika Charles Sanders Peirce serta Teori Metafora digunakan sebagai pisau analisis, dan ditemukan bahwa Majalah Tempo terbitan 16 September 2019 pada bagian karikatur atau ilustrasi sampulnya merupakan bentuk kritik masyarakat akan era kepemimpinan Jokowi sebagai presiden yang berhasil memenangkan kontestasi Pilpres selama dua periode tersebut. Pada penelitian ini, disimpulkan bahwa raut wajah merengut Jokowi beserta bayangan hidung Pinokio; secara implisit merupakan wujud metafora dari kekecewaan rakyat akan sosok pemimpin yang telah ingkar terhadap komitmen pemberantasan tindak pidana korupsi.
\end{abstract}

Kata kunci: Joko Widodo; metafora; semiotika; Peirce; Tempo

Korespondensi: Theodora Edra Pramaskara, S.IP., Fakultas Ilmu Sosial dan Ilmu Politik Universitas Indonesia, Jl. Salemba Raya No.4, Kec. Senen, Kota Jakarta Pusat, DKI Jakarta 10430, Email: theodora.edra01@ui.ac.id

Menyerahkan: Oktober 2021, Diterima: Desember 2021, Terbit: Januari 2022

ISSN: 2549-0559 (cetak), ISSN: 2549-1946 (online), Website: http://jurnal.unpad.ac.id/kajian-jurnalisme 
210 | Kajian Jurnalisme

Volume 05 Nomor 02 Tahun 2022

DOI: $10.24198 / \mathrm{jkj} . v 5 \mathrm{i} 2.36251$

\section{PENDAHULUAN}

Pada era modern, majalah merupakan salah satu media massa yang mengalami perubahan besar dalam hal penyampaian dan penyajian informasi. Persaingan majalah sebagai salah satu bentuk media cetak dalam menanggapi kehadiran media daring, menyebabkan para redaktur majalah harus bekerja lebih keras demi tetap dapat menarik dan mendapatkan tempat di tengah masyarakat. Salah satu unsur utama sebuah majalah dapat menarik perhatian masyarakat, terletak pada sampul majalah tersebut (Suptandar, 2018). Redaktur majalah pun terus berlomba-lomba untuk menghasilkan ilustrasi yang merupakan perpaduan antara teks dan visual, yang secara tepat dapat memberikan gambaran kepada masyarakat terkait berita dan informasi seperti apa yang akan mereka dapatkan dari majalah tersebut. Tak jarang, ilustrasi pada sampul majalah memuat unsur kritik, terutama yang ditujukan bagi pemerintahan, yang dapat membuka kemungkinan terjadinya ruang diskusi, serta penafsiran dan asumsi mengenai makna yang ada pada ilustrasi.

Sebelumnya, sudah sejak dahulu ilustrasi berupa karikatur dan kartun marak digunakan sebagai sarana penyampaian kritik terhadap pemerintah. Di negara-negara Barat, para kartunis memiliki kebebasan untuk mengekspresikan gagasannya dalam bentuk gambar, tanpa harus disertai risiko jeratan hukum. Di Amerika Serikat pada awal tahun 1900-an misalnya, The Masses, sebuah media massa beraliran kiri menampilkan kartun pada poster dengan tulisan "Wanted" dan "Reward" serta ilustrasi wajah Yesus Kristus yang dilengkapi dengan tulisan berartikan "Dicari untuk tindakan hasutan, kriminal anarkis, serta konspirasi untuk menggulingkan pemerintahan" (Iskandar, 2018). Penggunaan kartun dan karikatur sebagai kritik juga ditemukan pada media massa nasional Amerika, MAD (Roikan, 2019). Pada edisi Februari 2016, MAD menampilkan ilustrasi wajah sosok laki-laki mirip Donald Trump dengan raut wajah yang konyol pada halaman sampulnya. Ilustrasi dilengkapi dengan kalimat "20 Dumbest People, Events and Things 2015. Guess who's \#1?" atau berartikan “20 Orang, Acara, dan Hal Terbodoh di Tahun 2015. Tebak Siapa pada Urutan Pertama?" Selain itu, terdapat kalimat lain yang merupakan plesetan dari slogan Trump semasa kampanye, yakni, "Make America Dumb Again!"

Di Indonesia, prinsip kebebasan pers mulai terasa pada pasca era Orde Baru, melalui disahkannya UU No. 40 tahun 1999 tentang pers yang dengan jelas menyebutkan bahwa kemerdekaan pers adalah hak asasi warga negara (Roikan, 2019). Kebebasan berekspresi melalui media massa pun menjadi cukup terjamin, dengan mulai maraknya ilustrasi politik yang menampilkan kritik terhadap pemerintah pada era kepemimpinan Presiden tahun 20042014, Susilo Bambang Yudhoyono (SBY). Misalnya dalam penelitian yang berjudul "Modalitas Visual Kartunis dalam Kartun Politik Online Pascareformasi," era reformasi disebutkan sebagai era baru bagi kebebasan pers, dan para kartunis bebas untuk mengekspresikan kritik tanpa dihantui ancaman hukum pidana (Darmawan, 2016). Dalam hal ini, kritik yang dimunculkan kerapkali menampilkan SBY, dan tak lepas dari perspektif kebebasan pers ala Barat yang pada saat itu tertanam melalui penyebaran film-film produksi Hollywood.

Hal tersebut menunjukkan bahwa pada dasarnya ilustrasi berupa karikatur atau kartun di media massa, khususnya yang bertemakan politik, merupakan bagian dari bentuk komunikasi politik. Penggambaran tokoh politik menjadi tak terlepas bagian dari proses penyampaian pesan pada ranah komunikasi visual. Kartun politik dapat disebut sebagai simbolik atau representasi yang pada umumnya menyoroti pemerintahan serta kehidupan bermasyarakat dan bernegara. Ilustrasi pada kartun politik dapat mengandung humor, lelucon, hingga sindiran, dan satir, yang membuat ilustrasi menjadi semakin menarik (Darmawan, 2016).

Apabila dilihat dari kriteria ilustrasi sampul majalah yang mampu menarik perhatian 
masyarakat, majalah Tempo adalah salah satu media cetak yang memiliki daya tarik tersebut, karena menampilkan sampul dengan ilustrasi yang sarat akan makna kritis serta berani (Nusa, 2016). Bagi suatu media, ciri khas pada halaman sampul merupakan elemen penting yang menunjukkan ideologi. Untuk memahami serta menggali lebih dalam makna yang berusaha ditunjukkan oleh redaktur majalah Tempo, perlu dilakukan analisis unsur semiotika. Analisis semiotika secara singkat mempelajari makna dari adanya tanda-tanda, sehingga dapat memudahkan seseorang untuk mengetahui pesan serta makna yang tersampaikan dari suatu simbol. Adapun tujuan dari dilakukannya analisis semiotika adalah untuk menemukan berbagai makna tersembunyi yang berada di balik sebuah tanda, baik itu yang berupa teks, berita, ataupun berbagai bentuk tanda lainnya. Dalam semiotika, dipelajari berbagai hal yang dapat dianggap sebagai tanda - yang dapat merepresentasikan pemikiran seseorang — serta menolak adanya tanda yang bersifat ataupun memiliki makna absolut. Pemikiran terkait pengguna tanda tersebut merupakan hasil dari pengaruh berbagai konstruksi sosial (Mudjiyanto \& Nur, 2013). Untuk dapat memaknai suatu tanda, dibutuhkan adanya bahasa serta penggunaan kode kultural agar makna dapat terbentuk dan terkomunikasikan. Makna yang terbentuk selanjutnya akan saling mengacu satu dengan yang lainnya, yang merupakan hasil konvensi dari konstruksi sosial, serta terorganisasi dalam relasi antar berbagai tanda (Ramlan \& Supratman, 2019).

Pada 16 September 2019, redaktur Tempo menerbitkan edisi yang menampilkan sampul dengan ilustrasi karikatur Presiden Jokowi dengan bayangan menyerupai tokoh Pinokio yang hidungnya akan memanjang jika diketahui berbicara bohong. Ilustrasi pada sampul tersebut juga disertai teks yang berjudul "Janji Tinggal Janji". Sampul dengan ilustrasi demikian kemudian menuai kontroversi, pasalnya dilakukan bertepatan dengan momentum pengesahan RUU KPK oleh presiden, dan dinilai sarat akan unsur penghinaan terhadap presiden. Kontroversi kemudian berlanjut dengan adanya laporan terhadap Dewan Pers yang dilayangkan oleh Relawan Jokowi Mania (Jokman), atas karikatur yang dinilai menghina pemimpin negara tersebut (Prabowo, 2019). Di lain sisi, sebagian kelompok masyarakat justru menilai bahwa sampul tersebut hanya merupakan wujud metafora atas dinamika yang terjadi di tengah masyarakat. Seperti misalnya tuduhan para penggiat antikorupsi yang meyakini presiden memang tak tepat janji dalam konteks penguatan KPK. Lebih lanjut, pihak Istana Negara memberikan respons bahwa Istana sesungguhnya memahami peran dan fungsi jurnalisme yang ada di tengah masyarakat, dan menganggap kritik justru sebagai bagian penting dalam pemerintahan (Sani, 2019).

Perdebatan yang berkembang di tengah masyarakat tersebut, menyebabkan perlu adanya penelitian lebih lanjut terhadap sampul majalah Tempo. Selain itu, analisis perlu dilakukan mengingat masih minimnya studi terhadap sampul majalah Tempo yang bermakna kritis dan menuai kontroversi. Oleh karena itu, penelitian ini berusaha menganalisis sampul majalah Tempo edisi 16-22 September 2019, dengan menggunakan Semiotika Peirce. Hal demikian dikarenakan ilustrasinya yang menuai kontroversi dan dianggap merupakan penggambaran atas kritik masyarakat luas terhadap Presiden Jokowi, yang dinilai tidak setia pada janji penguatan lembaga anti-rasuah, Komisi Pemberantasan Korupsi atau KPK (Prabowo, 2019).

Merujuk pada situasi tersebut, pada akhirnya memunculkan pertanyaan yakni, bagaimana makna yang terdapat pada sampul majalah Tempo terbitan 16 September 2019, yang menampilkan ilustrasi Presiden Jokowi beserta bayangan hidung tokoh Pinokio? Adapun tujuan dari penelitian ini untuk mengetahui makna dan realitas di balik wacana sampul majalah Tempo 16 September 2019 “Janji Tinggal Janji” dengan karikatur atau ilustrasi Presiden Jokowi dengan bayangan hidung Pinokio. Tujuan lainnya untuk memberikan informasi mendalam kepada masyarakat terkait pesan serta makna tersirat yang ingin disampaikan dalam tanda atau simbol yang terkandung dalam ilustrasi sampul majalah tersebut. 
Kajian terdahulu terkait semiotika telah dilakukan terhadap beberapa sampul majalah Tempo. Dalam Kusumastuti dan Diana (2015), analisis semiotika dilakukan terhadap sampul majalah Tempo edisi 23 Februari 2015, dengan menggunakan analisis semiotika Peirce. Pada pembahasan ditemukan bahwa makna sampul majalah yakni terkait proses panjang pencalonan Kepala Kepolisian Republik Indonesia baru. Pada saat itu terdapat nama Budi Gunawan dalam pencalonan yang diisukan akan segera disahkan menjadi Kapolri, namun nyatanya posisi yang digadang-gadang jatuh ke tangannya tersebut tergantikan oleh Badrodin Haiti. Sementara itu, Badrodin Haiti diketahui merupakan kandidat yang tidak diutamakan untuk terpilih. Keputusan ini terjadi karena presiden disinyalir sedang berusaha untuk menekan segala persoalan antara Polri dan KPK. Pesan tersebut kemudian sampai kepada masyarakat melalui ilustrasi sampul, yang sejalan dengan pembahasan pada majalah (Kusumastuti \& Diana, 2015). Setelah dilakukan analisis semiotika, ditemukan bahwa berbagai simbol yang ada pada satu ilustrasi mampu merangkum suatu peristiwa yang terjadi dalam kurun waktu yang panjang. Hal serupa juga tampak pada studi Verian dan Situmeang (2019), yang berupaya menganalisis sampul majalah Tempo Edisi 19 November 2018. Ditemukan bahwa sebuah ilustrasi pada sampul tersebut nyatanya merangkum perjalanan panjang kampanye partai politik jelang Pemilu 2019. Kompleksitas simbol yang ingin ditampilkan tentunya memerlukan analisis semiotika agar makna yang didapatkan pembaca menjadi sesuai atau tidak berseberangan dengan maksud dari ilustrasi.

Tidak jauh berbeda, analisis semiotika Peirce juga ditemukan pada penelitian Dwiyanto dan Wiharto (2020). Dalam penelitiannya, analisis dilakukan menggunakan Triangle of Meaning Theory oleh Peirce, yang terdiri dari interpretant, representamen, dan object. Peirce selanjutnya membagi tanda berdasarkan tiga aspek yakni ikon, indeks, dan simbol. Peneliti kemudian menganalisis makna sampul majalah Tempo edisi 25 Februari mengacu pada tandatanda yang dikaitkan dengan teori Peirce yang telah ada. Pada sampul diilustrasikan Jokowi menghadap Prabowo, namun cenderung tampak ke arah pembaca. Hal ini menunjukkan Jokowi sebagai seorang petahana memiliki kepercayaan diri yang cukup tinggi dalam menghadapi Pilpres 2019, karena dirinya yang berangkat dengan diusung oleh partai besar pada Pilpres 2019. Sebaliknya, Prabowo digambarkan menghadap belakang dari pembaca, namun juga menghadap ke Jokowi. Dengan menghadap ke arah Jokowi, Prabowo sebagai pihak yang menantang juga dinilai memiliki cukup kepercayaan diri dalam menghadapi Jokowi sebagai pesaingnya. Pada intinya, ilustrasi tersebut mencerminkan persaingan Pilpres 2019 yang masih berlangsung secara sengit, yang digambarkan melalui nuansa perang Bubat (Dwiyanto \& Wiharto, 2020).

Analisis yang dilakukan terhadap elemen-elemen serta kajian terhadap setiap tokoh yang ditampilkan pada suatu ilustrasi, pada akhirnya menghasilkan makna yang dapat dipahami dengan mudah oleh publik yang membacanya. Seperti misalnya analisis semiotika pada sampul majalah Tempo lainnya yakni pada edisi 4-11 Juni 2018 (Akbar, 2018). Pada sampul majalah tersebut, tampak ilustrasi yang cukup kompleks, di mana terdapat wajah seorang laki-laki paruh baya yang sebagian wajahnya terburai menjadi serpihan-serpihan kecil berbentuk simbol tagar atau "hashtag". Dengan menggunakan analisis semiotika Peirce, dipahami bahwa makna yang terkandung di dalamnya adalah mewakili dari fenomena tagar yang ada di media sosial dan ramai diperbincangkan oleh khalayak pada saat itu. Konteks di tahun 2018 adalah suasana menunggu pemilu 2019 mendatang. Meskipun masih akan lama diselenggarakan, namun sudah banyak masyarakat yang menyampaikan pendapatnya terkait dengan wacana Jokowi menjadi presiden kembali pada tahun 2019. Analisis semiotika yang digunakan sebagai pisau dalam menemukan makna, membuat ilustrasi pada sampul majalah yang sebelumnya cenderung sulit 
untuk dipahami, menjadi dapat dimengerti oleh publik yang melihatnya.

Berdasarkan kajian literatur tersebut, ditemukan bahwa teori semiotika Charles Sander Peirce paling relevan digunakan sebagai pisau analisis, untuk memudahkan ditemukannya makna pada ilustrasi sampul majalah. Meski demikian, tampak pula dari kedua penelitian tersebut, kajian yang menggunakan semiotika Peirce dan merujuk pada sampul Tempo dengan makna kritis serta cenderung kontroversial masih minim atau jarang ditemukan. Oleh karena itu, teori semiotika yang diperkenalkan oleh Peirce digunakan sebagai teori teks untuk menganalisis wacana yang terletak pada sampul majalah Tempo 16 September 2019 "JokowiPinokio".

Dalam konteks semiotika, Peirce selalu menekankan bahwa tanda adalah perwakilan dari sesuatu bagi seseorang. Tanda-tanda dalam visual atau ilustrasi dapat dipandang dari jenis tanda, yang selanjutnya digolongkan ke dalam semiotik-di antaranya yakni ikon, indeks, serta simbol. Pertama, ikon merupakan tanda yang memiliki kemiripan dengan objek yang diwakilinya, atau memiliki ciri yang sama dengan sesuatu yang dimaksud. Kedua, indeks adalah tanda yang memiliki hubungan berupa relasi sebab akibat dengan apa yang diwakilinya, atau disebut juga yakni tanda sebagai bukti. Ketiga, simbol adalah suatu tanda yang dikonvensikan, di mana merupakan sebuah perjanjian atau peraturan yang disepakati secara bersama-sama. Suatu tanda pastinya mengandung ikon, teks, dan simbol, karena ketiganya merupakan satu kesatuan (Sobur, 2004).

Peirce menyebut bahwa tanda adalah aspek yang pertama, objek kemudian menjadi aspek yang kedua, serta penafsirnya merupakan yang ketiga. Penafsiran juga dapat membangun semiotika tak terbatas, selama suatu penafsir atau gagasan yang membaca tanda sebagai tanda yang lain bisa ditangkap oleh penafsir lainnya (Mudjiyanto \& Nur, 2013). Terkait dengan hal ini, penafsir merupakan unsur yang harus ada dan sangat penting ketika mengaitkan tanda dengan objeknya, misalnya agar terdapat suatu tanda, maka perlu adanya penafsiran. Selanjutnya, agar tanda dapat digunakan, perlu ada sesuatu yang disebut sebagai ground. Sementara itu, tanda (representamen) selalu terdapat dalam hubungan segitiga yang saling memiliki keterkaitan atau tradik antara satu dengan yang lainnya, yakni antara ground, objek, dan interpretant.

Menurut Peirce, tanda sendiri terbentuk dari hubungan segitiga, yakni representamen, yang dalam arti tanda memiliki hubungan atau relasi dengan objek yang ditujunya. Relasi tersebut kemudian menghasilkan interpretant (Sobur, 2004). Dalam kajian semiotika, proses tiga tingkat yang terbentuk melalui triangle of meaning theory adalah suatu proses semiosis. Proses semiosis merupakan proses yang tidak berujung, atau tidak memiliki awal serta akhir, atau saling berelasi antara satu aspek dengan aspek yang lainnya. Atas dasar relasi tersebut, Peirce membentuk pembagian berdasarkan adanya tanda. Ground pada tanda dibagi menjadi tiga hal yakni sinsign, qualisign, dan legisign. Sinsign merupakan keberadaan atau situasi aktual dari suatu benda atau peristiwa yang terjadi pada tanda. Misalnya; kalimat "air sungai keruh," ingin memberikan tanda bahwa ada yang terjadi yakni hujan yang turun di hulu sungai, sehingga mengakibatkan hilir sungai menjadi keruh. Qualisign merupakan kualitas yang terdapat pada tanda, atau sesuatu yang tampak terlihat. Legisign merupakan norma yang terkandung dalam tanda, mencakup hal yang boleh dan tidak untuk diperbuat.

Tanda dibagi ke dalam tiga hal berdasarkan objeknya, yakni; indeks, ikon, serta simbol. Indeks merupakan tanda yang menunjukkan adanya hubungan yang bersifat sebab akibat atau kausalitas. Misalnya kemunculan asap yang merupakan tanda bahwa adanya api. Ikon merupakan tanda yang mirip seperti objek aslinya. Atau dapat dikatakan, ikon merupakan acuan yang memberikan pesan sesuai bentuk aslinya, misalnya peta atau fotografi. Sementara itu, simbol menunjukkan relasi antara penanda dengan tandanya, yang bersifat berdasarkan 


\section{4 | Kajian Jurnalisme \\ Volume 05 Nomor 02 Tahun 2022 \\ DOI: $10.24198 / \mathrm{jkj} . v 5 \mathrm{i} 2.36251$}

kesepakatan atau konvensi di tengah masyarakat. Misalnya, lampu hijau disepakati bahwa kendaraan berjalan. Sementara lampu merah disepakati bahwa pengendara harus berhenti. Selanjutnya menurut aspek interpretant tanda dibagi atas dicisign, rheme, serta argument. Dicisign atau dicent sign adalah tanda yang penampakannya sesuai dengan fakta dan realitas. Rheme merupaka tanda yang digunakan untuk memberikan pemaknaan yang mungkin dapat berbeda-beda. Terakhir, argument merupakan tanda yang secara langsung memberikan alasan terkait dengan sesuatu (Sobur, 2004).

Sementara itu, teori lain dalam penelitian ini adalah Teori Metafora. Teori ini digunakan sebagai pelengkap untuk melihat pemaknaan sampul Majalah Tempo secara substantif, yakni melihat makna sesungguhnya dari sebuah simbol. Menurut Punter (2007) fungsi metafora sendiri awalnya hanya dianggap sebagai suatu bentuk retoris, sehingga menyebabkan studi akan metafora hanya terfokus pada upaya untuk membedakan bahasa figuratif serta harafiah. Namun selanjutnya studi terhadap metafora semakin berkembang, dan pemahaman terhadap metafora semakin meningkat secara substantif. Metafora pun dinilai merupakan bagian dari komunikasi sehari-hari dan melekat dalam kehidupan manusia, seperti misalnya ungkapan waktu adalah uang. Sehingga dapat dikatakan metafora tidak sekadar perihal linguistik belaka, tetapi juga merupakan ungkapan pada sebuah sistem yang terkonseptual (Lakoff \& Johnson, 2020). Teori atau konsep metafora terdiri dari tiga bagian (Thibodeau, Matlock, \& Flusberg, 2019). Pertama, topik; merupakan konsep yang asing berupa benda hingga suatu hal yang dibicarakan. Kedua, citra; merupakan konsep lain yang sudah dipahami, atau merupakan bagian metafora dari suatu majas serta ungapan yang difungsikan untuk mendeskripsikan sebuah topik ke dalam rangka untuk dibandingkan. Terakhir, titik kemiripan; merupakan bagian yang menunjukkan persamaan antara citra dengan topi. Tiga bagian yang menghasilkan metafora tersebut tidak akan selalu ditampilkan dengan eksplisit, di mana salah satunya bisa saja ditampilkan secara implisit.

Konsep metafora sendiri berkaitan erat dengan perspektif analisis wacana (Maslen, 2017). Dari perspektif analisis wacana, pemahaman terkait metafora bukanlah akhir, melainkan merupakan awal, untuk mengetahui 'urusan nyata' dari struktur yang mendasari, atau ranah tersembunyi dari representasi fenomena 'permukaan belaka'; yang dapat ditemukan dalam proses komunikasi. Terdapat dua pendekatan utama untuk mengidentifikasi metafora dalam analisis wacana. Pertama, analisis metafora dapat didekati secara top-down atau atas ke bawah, di mana peneliti berangkat dari konsep metafora, dan kemudian mencari ekspresi linguistik yang sesuai dengan konsepsi tersebut (Maslen, 2017). Kedua, pencarian kata-kata yang bersifat metafora dapat dilakukan dari bawah ke atas, tanpa perlu mengacu pada konsep metafora tertentu. Oleh karena itu, pendekatan ini menekankan pada proses induktif terhadap data korpus. Pada pendekatan ini, proses deduktif dinilai rentan terhadap hilangnya metafora.

Berdasarkan perspektif lainnya, metafora adalah semacam pemetaan yang merupakan hasil dari pemikiran manusia (Dorst \& Pasma, 2010). Metafora mengacu pada pemetaan terhadap konsep dari berbagai domain, di mana domain sumber adalah istilah yang digunakan untuk memahami domain target. Lakoff dan Johnson (2020) menyatakan bahwa penyampaian metafora dari makna non-literal dipahami dengan cara membangun pemetaan, yang menghubungkan antara dua domain yang berbeda; di mana pemetaan metaforis adalah pengungkapan dari satu kelompok konseptual terhadap kelompok lainnya. Pada akhirnya, akan ada serangkaian hubungan sistematis antara hal yang satu dengan yang lainnya, atau secara teknis, hubungan konsep ini sering disebut sebagai pemetaan. 
Volume 05 Nomor 02 Tahun 2022

DOI: $10.24198 / j k j . v 5 i 2.36251$

\section{METODE}

Penelitian ini menggunakan pendekatan kualitatif. Pendekatan kualitatif berupaya untuk memperlihatkan dunia sosial dari segi persepsi, perilaku, persoalan, hingga konsep yang terkait dengan objek yang diteliti. Dengan kata lain, Penekanan dari pendekatan kualitatif terletak pada penjelasan mengenai bagaimana gejala sosial terbentuk dan diberi pemaknaan (Neuman, 2011). Pendekatan kualitatif digunakan pada penelitian ini karena pendekatan tersebut bersifat subjektif. Asumsi dasar penelitian semiotika adalah kajian mengenai tanda, di mana saat memberikan pemaknaan pada tanda, setiap orang akan memiliki pandangan yang berbeda-beda merujuk pada ideologi, pengalaman, budaya, maupun latar belakang lainnya (Mudjiyanto \& Nur, 2013). Selanjutnya terkait dengan prosedur atau tata cara dalam pengumpulan data, akan dilakukan melalui studi kepustakaan atau tinjauan literatur. Data untuk tinjauan literatur terdiri dari majalah Tempo terbitan 16 September 2019, data yang berkaitan dengan topik penelitian, majalah-majalah terbitan Tempo lainnya yang terkait, visi misi dan sejarah redaktur majalah Tempo, hingga berbagai naskah penelitian terdahulu. Studi kepustakaan atau tinjauan literatur dilakukan baik secara cetak ataupun daring. Studi kepustakaan secara daring dilakukan dengan mengamati teks dan gambar yang ada di layar komputer. Data yang didapat juga bisa berwujud tekstual seperti unggahan atau pembicaraan melalui chat, maupun grafis seperti animasi, foto, dan video.

Sementara itu, paradigma yang digunakan sebagai kerangka berpikir adalah paradigma konstruktivisme. Dalam paradigma konstruktivisme, semesta yang ada merupakan hasil dari konstruksi sosial, dan berlandaskan pada ide bahwa realitas bukanlah sesuatu yang dibentuk secara objektif, tetapi dikonstruksi melalui proses interaksi dalam kelompok, masyarakat, dan budaya (Busti, 2019). Hal yang perlu ditekankan dari paradigma konstruktivis yakni menemukan bagaimana peristiwa atau realitas yang ada dikonstruksi dan selanjutnya realitas itu dibentuk. Pada penelitian ini, peneliti ingin menggali bagaimana makna dan realitas sosial yang dikonstruksikan pada ilustrasi sampul Jokowi dengan bayangan Pinokio. Oleh karena itu penggunaan paradigma konstruktivisme diperlukan, sehingga peneliti akan menemukan jawaban atas pertanyaan penelitian yang diajukan.

Jenis penelitian yang dilakukan adalah penelitian deskriptif. Penelitian deskriptif dimaksudkan untuk memberikan gambaran mengenai suatu gejela sosial tertentu. Sebelumnya sudah terdapat informasi mengenai gejala sosial serupa seperti yang dimaksud dalam suatu permasalahan penelitian, namun belum cukup memadai. Melalui penelitian deskriptif, akan terjawab berbagai pertanyaan yang menjadi kebaharuan dari penelitian sebelumnya, serta memberikan penjelasan yang lebih terperinci mengenai gejala sosial seperti yang dimaksudkan dalam suatu permasalahan penelitian terbaru atau penelitian yang bersangkutan. Penelitian deskriptif juga dilakukan terhadap variabel mandiri, yaitu tanpa membuat perbandingan atau menghubungkan dengan variabel yang lain (Busti, 2019).

\section{HASIL DAN PEMBAHASAN}

Sampul majalah dapat diibaratkan seperti helai pakaian dan atribut aksesori pelengkap lainnya pada tubuh seseorang, di mana publik akan terlebih dahulu memberikan ketertarikan ketika mereka melihat sampul majalah yang dirasa memiliki ciri khasnya sendiri. Menarik atau tidaknya sampul dari sebuah majalah, sangat bergantung dari jenis atau tipe majalah terkait, maupun konsistensi atau ideologi dari majalah tersebut untuk menampilkan ciri khas dan kekuatannya. Sejak awal, majalah Tempo identik dengan citra netralitas serta independensi sebuah media massa. Tempo hadir pada sebuah era di mana penolakan terhadap kepentingan partai politik dan sentimen antipartai sangat kuat dalam tubuh pers dan jurnalisme Indonesia. 
Setelah terbit dan beredar luas di tengah masyarakat, Tempo terbilang sukses menjalankan misinya sebagai majalah yang kritis dan independen. Majalah Tempo masih eksis hingga detik ini, kendati sempat diberangus pada rezim Soeharto tahun 1994 (Sucahya, 2017). Pada majalah Tempo, tampak sebagian besar menampilkan karikatur yang unik dan cenderung eksentrik untuk menarik minat serta ketertarikan dari para pembacanya. Namun lebih dalam, selain untuk menarik perhatian pembaca, sampul majalah Tempo juga sangat sarat akan penyampaian kritik sosial atas isu aktual yang tengah berkembang di antara masyarakat. Hal ini sejalan dengan pengertian dari karikatur itu sendiri, yang merupakan gambar atau ilustrasi dengan sifat lelucon, namun membawa pesan berupa kritik sosial (Resticka, 2017).

Merujuk pada analisis makna, tanda atau simbol yang ditampilkan pada sampul majalah Tempo, baik yang berupa visual (warna atau ilustrasi) maupun tipografi (teks atau tulisan), menimbulkan banyak pertanyaan terkait makna yang terkandung di baliknya. Analisis terhadap makna dilakukan dengan mengacu pada pokok pemikiran Peirce, yang menekankan pada penggunaan segitiga makna atau Triangle of Meaning. Teori tersebut berusaha untuk mengaitkan antara tanda dengan interpretasi, terhadap tanda yang dihubungkan dengan logika, di mana komponennya terdiri atas tiga hal, yakni Representamen (tanda), Object (objek) dan Interpretant (interpretasi). Ketiganya kemudian saling terhubung hingga menghadirkan sebuah makna. Representamen menghasilkan objek yang ada di dalam pikiran, objek tersebut kemudian diinterpretasikan atau dihasilkan menjadi suatu makna.

Tabel 1. Analisis Triangle of Meaning

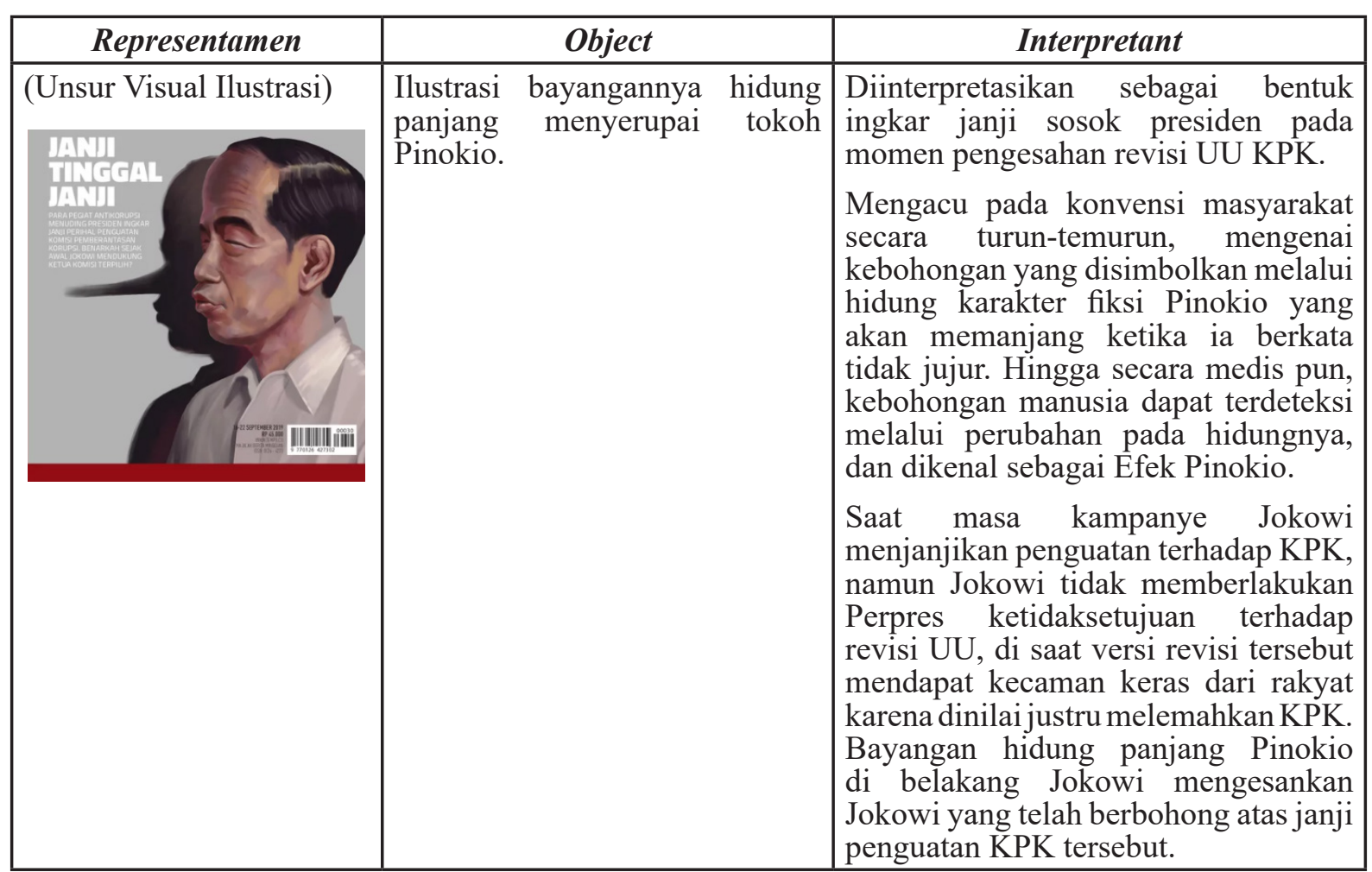




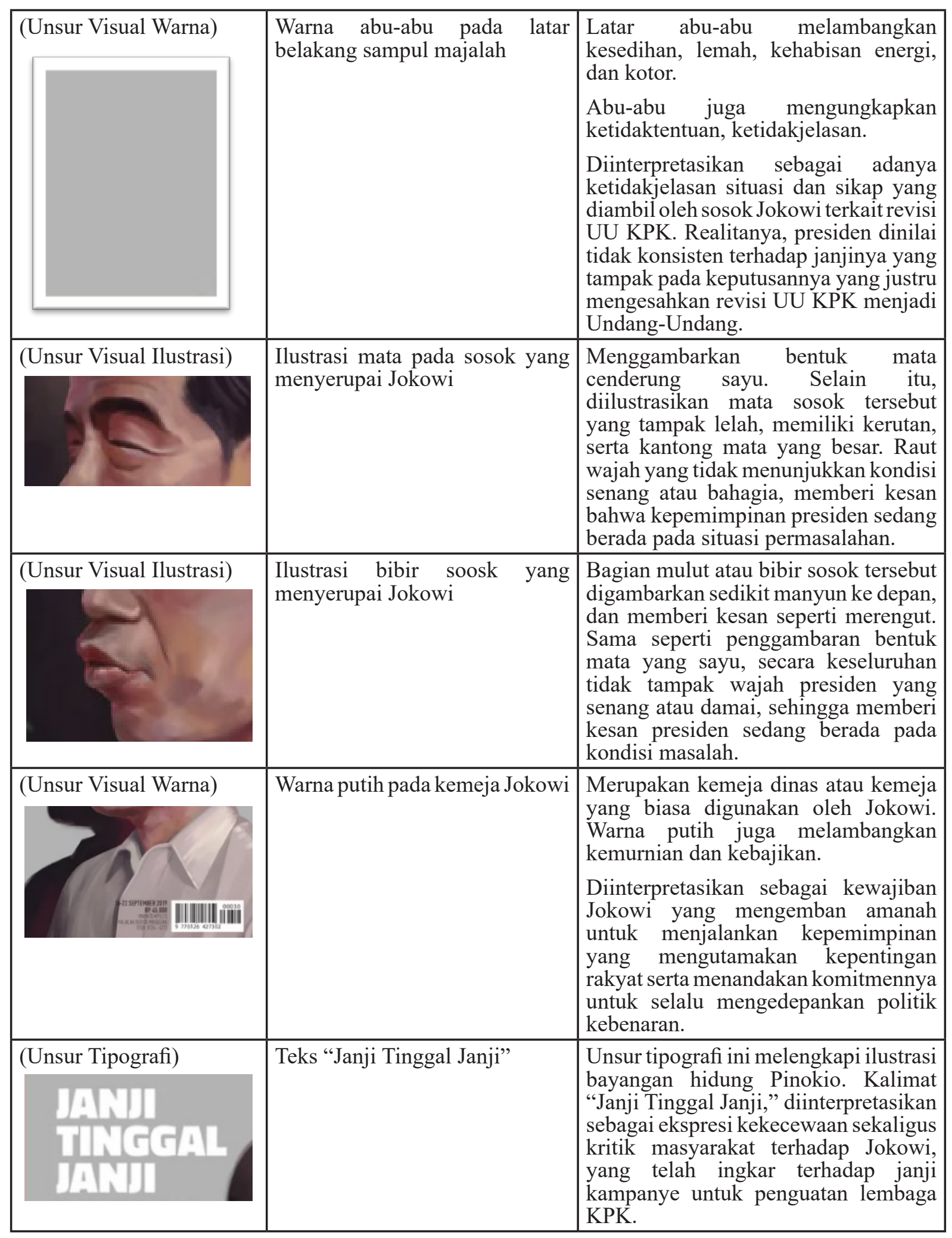

Sumber: diolah dari Prabowo (2019), Rizky (2019), Kompas.com (2008), Kumparan.com (2020)

Dalam teori Peirce, tanda selanjutnya diklasifikasikan menjadi tiga, yakni sinsign, qualisign, dan legisign. Sinsign adalah keberadaan benda serta peristiwa secara aktual, yang terdapat pada sebuah tanda (Sobur, 2004). Pada konteks sampul majalah ini, terdapat serentetan peristiwa yang melatarbelakangi redaktur majalah Tempo untuk menampilkan sampul yang 
terbilang kontroversial tersebut. Peristiwa pada September 2019 menjadi titik balik, ketika Dewan Perwakilan Rakyat (DPR) melakukan pengesahan terhadap revisi UU KPK, dan Jokowi pada saat itu tidak memberikan respon berupa penggunaan haknya dalam mencanangkan Peraturan Presiden, yang dianggap sebagai satu-satunya harapan untuk menyelamatkan independensi dan kredibilitas lembaga anti rasuah tersebut dalam memberantas korupsi. Ilustrasi tersebut mencerminkan sikap rakyat yang sudah muak atas lembaga legislatif serta pemerintah yang dinilai tidak serius terhadap segala janji pembangunannya. Situasi demikian yang pada akhirnya melatarbelakangi sinsign yang tampak pada sampul Jokowi Pinokio. Tanda tersebut dimaknai sebagai perwujudan kritis yang muncul mewakili kondisi rakyat dalam negara demokrasi yang dikecewakan oleh pemimpinnya. Dapat dilihat bahwa majalah Tempo pun telah menjalankan fungsi persnya untuk menyuarakan kegelisahan rakyat melalui ekspresi pada sampul tersebut.

Qualisign adalah kualitas yang ada pada tanda atau suatu hal yang sudah tampak nyata terlihat, di mana pada sampul majalah Tempo tersebut terdapat beberapa qualisign. Pertama, ilustrasi sosok yang menyerupai Jokowi yang digambarkan menggunakan kemeja putih dengan mata terpejam yang tampak lelah serta bibir yang merengut. Penggambaran demikian menunjukkan kondisi yang sedang tidak baik-baik saja, bahwa ia memikul beban yang berat atas situasi pengesahan revisi UU KPK kala itu. Kedua, bayangan tokoh Pinokio di belakang ilustrasi Jokowi menujukkan adanya janji yang kemudian diingkari, dengan lolosnya peraturan baru KPK tersebut menjadi produk Undang-Undang; di mana pengesahannya justru memberi celah bagi pelemahan lembaga anti rasuah tersebut. Ketiga, latar belakang sampul berwarna abu-abu yang melambangkan kesedihan, kelemahan, ketidaktetuan, ketidakjelasan (Kompas. com, 2008). Tanda ini pun dilengkapi dengan teks "Janji Tinggal Janji”; di mana kedua tanda tersebut merujuk pada sikap Jokowi yang dinilai inkonsisten terhadap janji kampanyenya.

Legisign merupakan norma yang ada di dalam tanda, terkait apa hal yang boleh dan tidak boleh dilakukan. Dalam konteks ini, legisign tampak pada sampul majalah Tempo yang menampilkan ilustrasi sarat akan pelanggaran terhadap norma kejujuran atau konsistensi. Ilustrasi menyerupai Jokowi yang disandingkan bersamaan dengan ilustrasi hidung panjang dari tokoh Pinokio, merupakan suatu perumpamaan atau metafora yang hadir melalui simbol; di mana simbol tersebut diketahui melambangkan sebuah tindakan ingkar janji. Secara historis, simbol ingkar janji melalui penggambaran hidung panjang berawal dari kemunculan tokoh fiksi Pinokio, yang dikisahkan sebagai anak yang bagian tubuh yakni hidungnya akan menjadi semakin panjang bila ketahuan berbicara tidak jujur. Selanjutnya, hidung panjang Pinokio menjadi simbol yang dikonvensikan dari generasi ke generasi, sebagai tanda kebohongan. Bahkan dalam bidang kesehatan, penelitian dari Universitas Granada di Spanyol menemukan bahwa, ketika manusia berbohong, akan terjadi perubahan pada hidungnya. Hal tersebut pun dikenal dengan nama efek Pinokio (Kumparan.com, 2020).

Sementara itu, metafora hadir sebagai bentuk interaksi yang terjadi antar instrumen kognitif, dan ekspresi dari sebuah metafora merupakan suatu ornamen retoris. Metafora dapat digunakan dan kian menjadi bagian tidak terpisahkan dari performa berbahasa sehari-hari (Lakoff \& Johnson, 2020). Kusmanto (2019) menyampaikan pemaknaan metafora bukan sekadar intepretasi metaforis yang merupakan alternatif dari adanya intepretasi harfiah, namun juga adalah ekspresi bahasa dalam kehidupan sehari-hari yang banyak terbentuk atas dasar sebuah struktur metaforis. Misalnya, dalam konteks sampul majalah Tempo, ilustrasi bayangan hidung panjang dari tokoh Pinokio, yang disandingkan bersamaan dengan karikatur atau ilustrasi sosok Jokowi, merupakan variasi metafora yang merupakan manifestasi dari tampilan karakter atau sifat kepribadaan seseorang yang pembohong. Dalam hal ini, Jokowi yang diyakini oleh 
masyarakat telah ingkar terhadap janji penguatan KPK. Lebih lanjut, mengacu pada unsur lesisgin dalam karikatur tersebut, juga menunjukkan bahwa terdapat makna yang menjelaskan perihal keberadaan representasi ilustrasi sebagai bentuk ekspresi kritik masyarakat kepada pemerintah atas peristiwa yang terjadi saat itu.

Selanjutnya berdasarkan perspektif objek, tanda dibagi atas 3 hal, yakni indeks, ikon, dan simbol. Indeks adalah tanda yang memiliki relasi kausalitas atau sebab akibat dengan apa yang diwakilinya, atau disebut tanda sebagai bukti. Unsur indeks yang tampak dalam sampul majalah ini disajikan dengan sebuah ilustrasi yang merupakan hasil dari sikap Jokowi terhadap revisi UU KPK yang dinilai justru melemahkan penegakkan anti korupsi di Indonesia. Kausalitas yang timbul adalah sampul majalah yang menampilkan ilustrasi menyerupai Jokowi beserta bayangan tokoh Pinokio, dapat diartikan sebagai bentuk kritik atas sikap ingkar janji presiden.

Ikon merupakan tanda yang mirip dengan objek yang diwakilinya, atau memiliki ciri yang menyerupai apa yang dimaksudkan. Pada sampul Majalah Tempo "Janji Tinggal Janji", terdapat satu ikon yaitu Jokowi. Walaupun digambarkan hanya satu sisi wajahnya saja secara menyamping, namun dapat terlihat jelas bahwa itu adalah ilustrasi seorang Jokowi. Jokowi ditampilkan selayaknya dirinya sebagai seorang presiden, dengan raut wajah yang sama serta mengenakan pakaian kepresidenan khasnya yang berwarna putih. Penggambaran Jokowi secara menyamping pun turut memberi penegasan atas ilustrasi bayangan berwarna hitam dengan siluet hidung tokoh Pinokio yang tampak jelas di belakang Jokowi.

Sementara simbol adalah sebuah tanda yang dikonvensi, yakni merupakan perjanjian serta peraturan yang disepakati bersama. Simbol yang muncul pada sampul ini adalah ilustrasi Jokowi dengan bayangan hidung panjang Pinokio. Jokowi sendiri merupakan tokoh politik yang mengawali kariernya sebagai Walikota Solo dari 2005 sampai 2012. Pada tahun 2012 pula, ia terpilih sebagai Gubernur DKI Jakarta. Jabatan yang hanya diemban selama dua tahun lamanya karena dirinya yang kemudian memenangkan dua kontestasi Pilpres yakni pada 2014 dan 2019. Sebagai seorang politisi dan presiden, Jokowi selalu menampilkan citranya sebagai pribadi yang sederhana; dengan model potongan rambut belah yang klimis, serta gaya berpakaian yang seringkali menggunakan produk lokal atau karya anak bangsa, hingga kemeja putih polosnya yang sangat ikonik. Hal tersebut yang menjadi gaya dan ciri khas Jokowi yang tertanam dalam benak khalayak. Melalui analisis simbol, selanjutnya dapat disimpulkan secara jelas, siapa saja ilustrasi yang ditampilkan oleh majalah Tempo, meskipun tanpa menyertakan secara eksplisit atau harfiah tokoh-tokoh yang ada di dalamnya. Ilustrasi pria dengan kemeja putih dan gaya rambut tersebut dapat ditafsirkan sebagai sosok Jokowi, dengan tokoh Pinokio di belakangnya yang merupakan simbol kebohongan. Pada akhirnya dapat dikatakan bahwa suatu tanda, pasti mengandung tiga unsur baik ikon, teks, maupun simbol; sebagai satu kesatuan yang akan menghasilkan penafsiran tersendiri.

Berdasarkan interpretasinya, tanda dibagi atas rheme, dicent sign atau dicisign, dan argument. Rheme adalah tanda yang membuat pihak yang melihatnya untuk memberikan pemaknaan yang mungkin berbeda-beda. Dalam sampul majalah Tempo ini, unsur rheme tampak pada latar belakang dengan warna abu-abu. Meskipun warna tersebut dapat diartikan sebagai kelemahan dan ketidakjelasan (Kompas.com, 2008), namun penafsiran tersebut masih dapat berubah merujuk pada konteks pemahaman pihak yang melihatnya. Menurut filosofi masyarakat tertentu, warna abu-abu juga dapat diartikan sebagai warna yang netral, mengartikan kedewasaan, atau juga mencerminkan fokus serta keseriusan.

Sementara itu, dicisign adalah tanda yang sesuai dengan realitas atau fakta yang nyata. Dicisign pada sampul majalah Tempo tampak pada ilustrasi sosok pria yang digambarkan mirip seperti Jokowi. Sosok tersebut dapat ditafsirkan sebagai Jokowi karena ciri-ciri dan kekhasan 
yang secara realita ada pada seorang Jokowi. Misalnya dapat dilihat melalui gaya rambut serta pakaian kemeja putih polos yang dikenakan. Tampak gaya rambut pada ilustrasi bermodel cepak dan rapi, khas dengan gaya rambut sehari-hari Jokowi. Sementara itu, pakaian kemeja putih polos juga sangat identik dengan model berpakaian Jokowi, bahkan semenjak masa awal melakukan kampanye sebagai calon presiden. Baik dari raut wajah, bentuk fitur mata, hidung, dan mulut, serta model rambut dan pakaian, merupakan realitas yang ditampilkan oleh Jokowi ketika berada di hadapan publik. Terakhir, argument adalah tanda yang memberikan adanya suatu alasan secara langsung. Pada sampul majalah Tempo, penempatan sosok Pinokio yang hanya sebagai bayangan, bahkan hanya bagian hidungnya saja atau tidak secara utuh, menunjukkan suatu alasan secara langsung pemilihan tokoh tersebut. Satu hal yang paling identik dari tokoh Pinokio adalah bagian hidung. Bayangan hidung Pinokio yang ada di belakang sosok Jokowi secara langsung dan sangat jelas menjadi simbol kebohongan. Hal tersebut menunjukkan alasan bahwa tindakan Jokowi memiliki konsekuensi untuk dikritik oleh publik yang merasa telah diingkari atas komitmen dan janji Jokowi mengenai penguatan lembaga KPK.

\section{SIMPULAN}

Tempo edisi 16 September 2019 menampilkan sampul kontroversial yang menyertakan ilustrasi tokoh seorang pria dengan raut wajah merengut, disertai bayangan yang memiliki hidung memanjang. Berdasarkan analisis simbol, tokoh pria dengan raut wajah, gaya rambut, serta kemeja putih polos sangat identik dengan sosok Jokowi pada realitanya, begitu pula dengan bayangan hidung panjang yang sangat identik dengan tokoh Pinokio. Pun ditegaskan melalui analisis dicent sign bahwa tokoh Pinokio merupakan simbol kebohongan, serta raut wajah Jokowi yang merengut menggambarkan suasana genting atau tidak baik-baik saja. Jika merujuk pada unsur analisis sinsign, situasi demikian mengacu pada sikap Jokowi yang tidak menerbitkan Peraturan Presiden demi membatalkan revisi UU KPK yang sebelumnya sudah diloloskan oleh DPR. Peristiwa tersebut mencerminkan sikap kekecewaan rakyat terhadap presiden yang tidak menepati janji masa kampanyenya dalam hal penguatan lembaga anti korupsi. Alih-alih menguatkan, Jokowi justru mengambil langkah memuluskan jalan peralihan KPK, dari lembaga independen, menjadi lembaga di bawah kendali pemerintah. Melalui analisis tanda atau representamen, object, serta interpretant yang diperkenalkan oleh Peirce, dapat disimpulkan bahwa sampul Majalah Tempo hadir sebagai kritik keras masyarakat terhadap sikap Presiden Jokowi berkaitan dengan polemik revisi Undang-Undang KPK. Ilustrasi Jokowi dengan bayangan hidung Pinokio secara implisit merupakan metafora dari sosok presiden yang dianggap ingkar janji terhadap rakyat. Karya redaktur majalah Tempo terbilang kontroversial karena menuai pro kontra dari kelompok masyarakat itu sendiri. Terlepas dari hal tersebut, majalah Tempo telah mengambil sikap kritis dan menjadi media yang menjalankan fungsinya sebagai corong rakyat, dan menuangkannya ke dalam ilustrasi-ilustrasi kreatif pada sampul majalahnya.

Penelitian ini berusaha mengonstruksikan makna dari tanda-tanda yang tampak pada sampul Majalah Tempo Jokowi dan bayangan hidung Pinokio melalui studi kepustakaan. Oleh karena itu, menjadi keterbatasan dalam penelitian di mana data penelitian tidak didukung oleh wawancara mendalam terhadap ilustrator dari sampul majalah itu sendiri. Berdasarkan hasil, diskusi penelitian, serta kesimpulan yang telah diuraikan, peneliti memberikan rekomendasi agar penelitian serupa selanjutnya dapat diperkaya dengan metode wawancara mendalam. Selain itu, studi lanjutan juga dapat dilakukan dengan menggunakan paradigma lain, seperti misalnya paradigma kritis dengan pendekatan teori semiotika yang diperkenalkan oleh Roland Barthes, 
Volume 05 Nomor 02 Tahun 2022

DOI: $10.24198 / j k j . v 5 i 2.36251$

untuk melihat fenomena atau makna dari sampul Majalah Tempo dari sisi lain. Penelitian juga dapat dilakukan dengan membandingkan antara sampul edisi Jokowi dan bayangan Pinokio, dengan sampul Majalah Tempo sejenis lainnya yang juga sarat akan tanda politik dan masalah sosial. Hal tersebut guna mendapatkan hasil penelitian yang lebih komprehensif, dan mampu mengetahui secara utuh makna dari representasi yang ingin disampaikan melalui ilustrasi tersebut.

\section{DAFTAR PUSTAKA}

Akbar, N. A. (2018). Analisis semiotika pada cover majalah Tempo edisi 4 - 11 Juni 2018. Jurnal Spektrum Komunikasi, 6(1), 61-66. https://doi.org/10.37826/spektrum.v6i1.55

Busti, F. I. (2019). Memahami pendekatan positivis, konstruktivis dan kritis dalam metode penelitian komunikasi. Communique, 2(1), 1-8. Diakses dari http://ejurnal.stikpmedan. ac.id/index.php/JIKQ/article/view/27

Darmawan, F. (2016). Modalitas visual kartunis dalam kartun politik online pascareformasi. Jurnal ILMU KOMUNIKASI, 13(1), 109-122. https://doi.org/10.24002/jik.v13i1.603

Dorst, A. G., \& Pasma, T. (2010). The cambridge handbook of metaphor and thought. Metaphor and Symbol, 26(1), 96-103. https://doi.org/10.1080/10926488.2011.535420

Dwiyanto, A., \& Wiharto, D. (2020). Analisis semiotika Charles Sanders Pierce pada cover majalah Tempo online edisi 25 Februari - 03 Maret 2019 (analisis semiotika Charles Sanders Pierce). Jurnal Pantarei, 4(3). Diakses dari https://jom.fikom.budiluhur.ac.id/ index.php/Pantarei/article/view/579

Iskandar. (2018). Metafora dalam kartun bertema korupsi karya G.M. Sudharta. INVENSI (Jurnal Penciptaan Dan Pengkajian Seni), 3(1), 15-22. https://doi.org/10.24821/invensi. v3i1.2103

Kompas.com. (2008). Psikologi warna. Diakses dari Kompas.com website: https://nasional. kompas.com/read/2008/12/19/16441165/ Properti Tips

Kumparan.com. (2020). Efek Pinokio: Hidung manusia berubah ketika berbohong. Diakses dari kumparan.com website: https://kumparan.com/lampu-edison/efek-pinokio-hidungmanusia-berubah-ketika-berbohong-1t9FME787T9

Kusmanto, H. (2019). Konseptualisasi metafora wacana politik: Studi semantik kognitif. WASKITA: Jurnal Pendidikan Nilai Dan Pembangunan Karakter, 3(2), 27-42. https:// doi.org/10.21776/ub.waskita.2019.003.02.3

Kusumastuti, R. D., \& Diana, M. (2015). Analisis semiotika pada cover majalah Tempo edisi tanggal 23 Februari-1 Maret 2015. SEMIOTIKA: Jurnal Komunikasi, 10(2), 335-368. Diakses dari https://journal.ubm.ac.id/index.php/semiotika/article/view/944

Lakoff, G., \& Johnson, M. (2020). Conceptual metaphor in everyday language. In Shaping Entrepreneurship Research (1st ed., p. 30). London: Routledge. https://doi. org/10.4324/9781315161921-21

Maslen, R. (2017). Metaphor and discourse. Metaphor and the Social World, 7(2), 300-307. https://doi.org/10.1075/msw.7.2.08mas

Mudjiyanto, B., \& Nur, E. (2013). Semiotika dalam metode penelitian komunikasi. Jurnal Pekommas, 16(1), 73-82.Diakses dari https://jurnal.kominfo.go.id/index.php/pekommas/ article/view/1160108

Neuman, W. L. (2011). Social research methods: Qualitative and quantitative approaches. London: Pearson.

Nusa, L. (2016). Halaman muka majalah Tempo (Studi analisis isi perbedaan halaman muka sebagai representasi tajuk utama majalah Tempo edisi Tahun 1993/1994 dengan Tahun 
222 | Kajian Jurnalisme

Volume 05 Nomor 02 Tahun 2022

DOI: $10.24198 / \mathrm{jkj} . v 5 \mathrm{i} 2.36251$

2009/2010). Profetik: Jurnal Komunikasi, 09(01), 22-31. https://doi.org/10.14421/pjk. v9i1.1188

Prabowo, H. (2019). Kontroversi cover Tempo: Saat kritik lewat karya dinilai menghina. Diakses dari Tirto.id website: https://irto.id/kontroversi-cover-tempo-saat-kritik-lewatkarya-dinilai-menghina-eifq

Punter, D. (2007). Public metaphor. In Metaphor (1st ed., p. 15). London: Routledge. https:// doi.org/10.4324/9780203965887-8

Ramlan, W., \& Supratman, L. P. (2019). Analisis semiotika Charles Sanders Peirce pada sampul majalah Tempo edisi satu perkara seribu drama. E-Proceeding of Management, 6(2), 4746-4757. Diakses dari https://openlibrarypublications.telkomuniversity.ac.id/index. php/management/article/view/10493

Resticka, G. A. (2017). Pemanfaatan aspek kebahasaan bentuk kata tuturan humor dalam karikatur. Haluan Sastra Budaya, 1(1), 41-60. https://doi.org/10.20961/hsb.v1i1.4296

Rizky, F. (2019). Makna di balik baju putih Jokowi - Ma'ruf Amin. Diakses dari Okezone.com website: https://news.okezone.com/read/2019/03/26/605/2035383/makna-di-balik-bajuputih-jokowi-ma-ruf-amin

Roikan. (2019). Bukan sekedar menggambar: Dinamika kartunis lepas Indonesia di era digital. Jurnal Pemikiran Sosiologi, 6(1), 27-40. https://doi.org/10.22146/jps.v6il.47465

Sani, A. F. I. (2019). Cover majalah Tempo, Istana: Presiden hormati kebebasan pers. Diakses dari Tempo.co website: https://nasional.tempo.co/read/1252836/cover-majalah-tempoistana-presiden-hormati-kebebasan-pers

Sobur, A. (2004). Analisis teks media: suatu pengantar untuk analisis wacana, analisis semiotik, dan analisis framing. Bandung: Remaja Rosdakarya.

Sucahya, M. (2017). Manajemen media digital. Tarbawi: Jurnal Keilmuan Manajemen Pendidikan, 3(01), 43-58. Diakses dari http://jurnal.uinbanten.ac.id/index.php/tarbawi/ article/view/1778

Suptandar, J. P. (2018). Teori dasar desain komunikasi visual. Jakarta: Djambatan.

Thibodeau, P. H., Matlock, T., \& Flusberg, S. J. (2019). The role of metaphor in communication and thought. Language and Linguistics Compass, 13(5), 1-18. https://doi.org/10.1111/ $\operatorname{lnc} 3.12327$

Verian, A., \& Situmeang, I. V. O. (2019). Representasi foto kampanye calon presiden pada majalah Tempo edisi 19-25 November 2018 (analisis semiotika Charles Sanders Peirce). SEMIOTIKA: Jurnal Komunikasi, 13(1), 1-21. https://doi.org/10.30813/s:jk.v13i1.1787 